УДК 332.02:504.03, DOI 10.31210/visnyk2018.04.16

(C) 2018

Писаренко П. В., доктор сільськогосподарських наук, професор, академік інженерної Академії Украӥни, Самойлік М. С., доктор економічних наук, Диченко О. Ю., кандидат сільськогосподарських наук

Полтавська державна аграрна академія

\title{
ВИКОРИСТАННЯ РІЗНИХ ТЕХНОЛОГІЧНИХ РІШЕНЬ У СФЕРІ ПОВОДЖЕННЯ З ТВЕРДИМИ ВІДХОДАМИ ПРИ ОЦІНЦ РИЗИКІВ ЩОДО ЗДОРОВ'Я НАСЕЛЕННЯ
}

\section{Рецензент - доктор сільськогосподарських наук, професор В. М. Писаренко}

Поводження з відходами є однією з найбільи важливих еколого-економічних та сочіальних проблем регіонального розвитку. У статті запропоновано методичні підходи до оцінювання ризику здоров'ю населення від забруднення довкілля під час поводження з твердими відходами, які включають комплексну інвентаризацію викидів забруднюючих речовин та оцінку експозииії; визначення ризику миттєвих токсичних ефектів та ризику хронічного впливу з урахуванням сукупної дії забруднюючих речовин на організм людини; розрахунок екологічного ризику з урахуванням економічного збитку від забруднення довкілля; прогноз сочіально-економічного розвитку регіону за різних технологічних рішень у сфері поводження 3 твердими відходами у залежності від рівня екологічного ризику.

Проведена оцінка впливу існуючої системи поводження з твердими відходами на здоров'я населення на прикладі Полтавської області дала змогу встановити, щчо найбільший ризик для здоров'я, як і економічний збиток від забруднення навколишнього середовища складає перший сценарій - існуюча ситуація. Найбільш ризикованим $і$ небезпечним для здоров'я населення є будівництво сміттєспалювальних заводів, тобто четвертий сценарій є неприйнятним для області. Обтрунтовано, щуо найменш ризикованим $i$ безпечним для здоров'я населення та навколишнього середовища в області є будівництво чотирьох сміттєсортувальних станиій або двох заводів із компостування.

Ключові слова: ризик здоров'ю населення, тверді відходи, регіон, технологічні рішення, населення.

Постановка проблеми. Однією з умов сталого територіального розвитку $\epsilon$ соціально-екологоекономічна рівновага регіону, що являє собою такий стан регіональних систем, під час якого забезпечується економічне зростання, соціальна стабільність і екологічна безпека регіону. Порушення даної рівноваги веде до виникнення збитків різного характеру: екологічних, економічних, соціальних.
Необхідним елементом соціально-екологоекономічної рівноваги регіону є ефективне функціонування сфери поводження з твердими відходами (TB).

Проблема поводження з відходами $є$ однією 3 найбільш важливих еколого-економічних та соціальних проблем регіонального розвитку. У той же час, потрібно враховувати, що обгрунтування інвестицій у сферу поводження з ТВ повинно спиратися на еколого-економічну оцінку різних технологічних рішень у даній сфері з урахуванням соціальних аспектів.

Аналіз останніх досліджень і публікацій, у яких започатковано розв'язання проблеми. Важливо відмітити, що проблема ефективного управління відходами в певній мірі вирішена у розвинутих країнах світу, в першу чергу - в Свропі, хоча, наприклад, «сміттєва криза» 20072008 pp. у м. Неаполь показала, що і західні спеціалісти, які мають великий досвід i наукові знання у сфері поводження з ТВ, не можуть стверджувати, що проблема повністю вирішена [1].

В останні роки в Україні з'явилася велика кількість наукових праць, присвячених даній тематиці, зокрема: О. І. Бондаря [2], В. С. Барановської, В. Л. Пілюшенка [3], О.В.Мороза, А. О. Свентуха [4], В. С. Міщенка, Г. П. Виговської [5] та ін. Але в даних розробках недостатньо відпрацьований практичний механізм отримання оціночних параметрів впливу відходів на стан навколишнього середовища, зокрема стан екосистем та здоров'я населення.

Метою даної роботи $є$ розробка та апробація методичних підходів до оцінювання ризику здоров'ю населення від забруднення довкілля під час поводження з твердими відходами.

Основні завдання - впровадити методику оцінки ризику здоров'ю населення від сфери поводження з ТВ на регіональному рівні. 


\section{СІЛЬСЬКЕ ГОСПОДАРСТВО. ЕКОЛОГІЯ}

Матеріали та методи досліджень. Методологічною базою дослідження стали наукові праці вітчизняних і зарубіжних вчених та нормативноправові акти у сфері поводження з ТВ.

Методичною базою дослідження стали загальнонаукові економічні методи, у тому числі такі як монографічний, порівняльний аналіз, картографічний та інші методи.

Результати досліджень. Одним 3 екологоекономічних критеріїв під час прийняття рішень у сфері поводження з ТВ може виступати екологічний ризик і ризик здоров'ю населення. Використання підходу, заснованого на методології оцінки ризику здоров'ю, дає змогу проводити прогнози ситуації та оцінити наслідки прийняття рішень.

На першому етапі оцінки ризику здоров'ю населення проводиться ідентифікація небезпеки, яка може бути занована на діючій системі інвентаризації забруднюючих речовин, що надходять в об’єкти навколишнього середовища в процесі поводження з ТВ.

На другому етапі проводиться оцінка експозиції, яка методологічно забезпечується математичним моделюванням процесу розповсюдження забруднюючих речовин у навколишньому середовищі, моніторингом довкілля.

Третій етап - оцінка залежності «доза ефект» - процес кількісної характеристики токсикологічної інформації, встановлення зв'язку між діючою дозою (концентрацією) забруднюючої речовини і випадками шкідливих ефектів у певній популяції (групі населення):

$$
R_{n}=1-\exp \left\{\ln (0.84)\left[\frac{c}{\mathrm{r} A K^{\prime} \cdot \kappa_{e}}\right]^{b}\right\}
$$

де C - середня концентрація речовини, що надходить в організм людини протягом його життя;

Ке - коефіцієнт небезпеки, який визначається залежно від класу небезпеки;

$\mathrm{b}$ - коефіцієнт ізоефективності, який враховує особливості токсичних властивостей речовин і приймається в залежності від класу небезпеки речовини.

На четвертому етапі, для використання певного значення ризику у якості оціночного критерію економічного показника, в разі прийняття рішень пропонується визначати ризик на основі вірогідності виникнення небажаної події (ризик здоров'ю населення) і розмірів наслідків:

$$
P=\sum_{i=1}^{n} R_{i} \cdot \Pi_{1},
$$

де $\mathrm{P}$ - економічно оцінений еквівалент ризику (розраховується окремо для кожного об'єкту природного середовища);

$\mathrm{R}$ - значення ризику як вірогідної характеристики - ризик здоров'ю людини;

$П$ - величина втрат у випадку настання несприятливої події.

У Полтавській області щорічно утворюється близько 480 тис. тонн $\left(1,6\right.$ млн м $\left.{ }^{3}\right)$ твердих побутових відходів, які видаляються на 377 санкціонованих полігонах та звалищах ТВ, та 4,5 млн тонн промислових відходів.

Спостерігається тенденція до щорічного утворення як промислових (у тому числі небезпечних), так і побутових відходів. Так, якщо у 2000 р. відходи, що утворюються в Полтавській області, становили 1,5\% від загального обсягу, який утворюється в Україні, то у 2016 р. - 8,5\%.

Зростає обсяг накопичених відходів у місцях організованого та неорганізованого складування. Так, станом на 1.01.2016 р. в області накопичено понад 15 млн тонн промислових відходів та 20 млн тонн ТПВ.

Загальна площа несанкціоновано видалених відходів у 2016 р. становила 60,2 га (411 одиниць) [7].

Значно зменшився обсяг утворення вторинної сировини (на $32 \%$ у 2016 p., у порівнянні 3 2010 р.) та її використання, що вказує на неефективність функціонування даної сфери у регіоні.

Проведемо оцінку потенційного та миттєвого ризику здоров'ю населення від існуючої сфери поводження з ТВ (на прикладі Полтавської області) та порівняємо із можливими сценаріями іiі технологічного переоснащення.

Перший сиенарій. Існуюча ситуація зберігається.

У даному випадку необхідно оцінити ризик від санкціонованих та несанкціонованих існуючих полігонів із використанням авторської методики оцінки збитку від забруднення довкілля полігонами і звалищами ТВ, наведеної у [6] (рис. 1).

Другий сценарій. На зміну існуючих звалищ вводяться регіональні полігони (сім полігонів для забезпечення повного видалення ТВ з урахуванням максимальної логістики транспорту, двоє із яких обслуговують міста Полтава і Кременчук, потужністю 200 тис. тонн, а п'ять - потужністю 50 тис. тонн.

При цьому можливим $є$ будівництво сміттєперевантажувальних станцій у разі відстаней транспортування до полігонів понад 20 км, що значно зменшить транспортні витрати. 


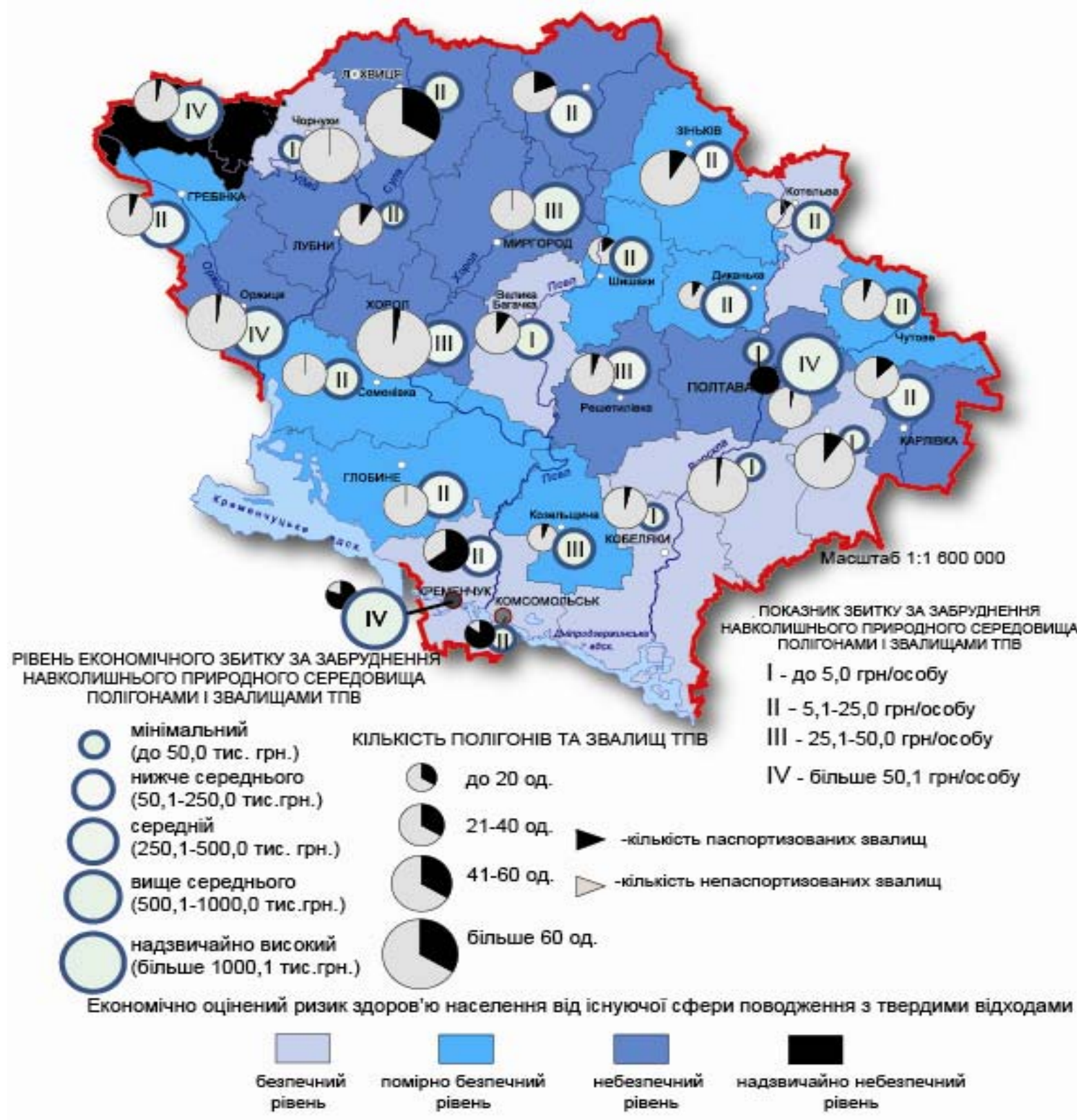

Рис. 1. Економічно оцінений ризик від забруднення навколищнього середовища існуючою системою поводження з твердими відходами (авторське дослідження)

Третій сиенарій. Будівництво чотирьох сміттєпереробних заводів (сумарною потужністю 1,2 млн м $\left.{ }^{3}\right)$. Залишок вивозиться на полігони ТВ (додатково - сім полігонів потужністю по 50 тис. тонн).

Четвертий сиенарій. Будівництво двох сміттєспалювальних заводів (м. Полтава, м. Кременчук), додатково семи полігонів потужністю по 50 тис. тонн.

П'ятий сиенарій. Будівництво двох установок з біокомпостування, додатково семи полігонів потужністю по 50 тис. тонн.

Порівняння існуючої ситуації з можливими сценаріями технологічного переоснащення сфери поводження з ТВ у Полтавській області наведено у табл. 1.

Висновок. Таким чином, авторами запропоновано методику оцінки ризику здоров'ю населення від сфери поводження з ТВ на регіональному рівні.

Проведена оцінка впливу існуючої системи поводження з твердими відходами на здоров'я населення на прикладі Полтавської області дала змогу встановити, що найбільший ризик для здоров'я, як і економічний збиток від забруднення навколишнього середовища складає перший сценарій - існуюча ситуація. 


\section{1. Порівняння існуючої ситуацї з можливими сценаріями технологічного переоснащення сфери поводжсення з ТВ у Полтавській області*}

\begin{tabular}{|c|c|c|c|c|c|c|c|c|c|c|c|}
\hline \multirow[t]{2}{*}{ Сценарії } & \multicolumn{3}{|c|}{$\begin{array}{c}\text { Забруднення } \\
\text { атмосфери }\end{array}$} & \multicolumn{3}{|c|}{$\begin{array}{c}\text { Забруднення } \\
\text { водного } \\
\text { середовища }\end{array}$} & \multicolumn{3}{|c|}{$\begin{array}{c}\text { Забруднення } \\
\text { грунтів }\end{array}$} & \multicolumn{2}{|c|}{$\begin{array}{c}\text { Сумарне } \\
\text { забруднення }\end{array}$} \\
\hline & 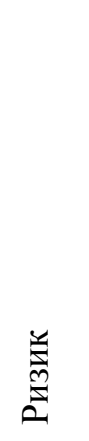 & 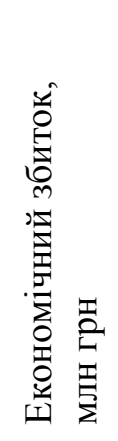 & 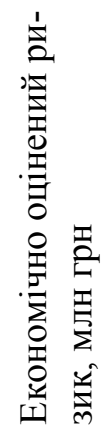 & 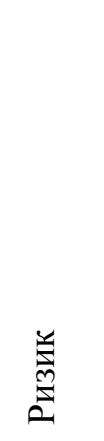 & 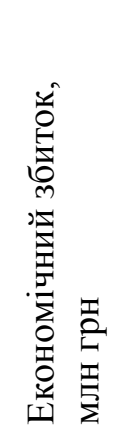 & 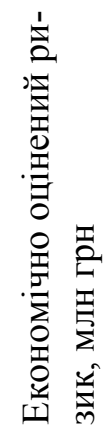 & 气ै & 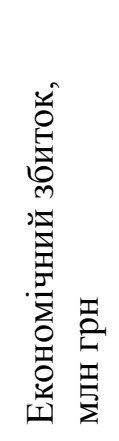 & 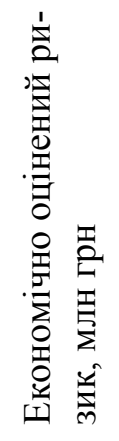 & 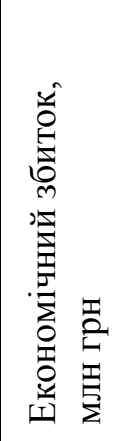 & 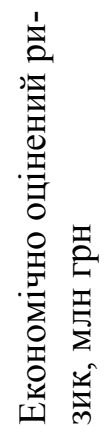 \\
\hline 1-й сценарій & 0,19 & 14,62 & 2,75 & 0,3 & 9,26 & 2,79 & 0,26 & 15,20 & 4,02 & 39,07 & 9,58 \\
\hline 2-й сц & 0,04 & 0,04 & 0,0 & 0,276 & 0,08 & 0,02 & 0,26 & 2,65 & 0,69 & 2,79 & 0,71 \\
\hline 3-й сценарій & 0,02 & 0,04 & 0,0 & 0,02 & 0,048 & 0,01 & 0,02 & 0,94 & 0,01 & 1,03 & 0,02 \\
\hline 4-й сценарій & 0,46 & 6,60 & 3,69 & 0,57 & 0,93 & 0,53 & 0,59 & 3,88 & 2,21 & 11,42 & 6,52 \\
\hline 5-й сценарій & 0,00 & 0,01 & 0,0 & 0,02 & 0,03 & 0,01 & 0,02 & 0,91 & 0,01 & 0,95 & 0,02 \\
\hline
\end{tabular}

* розрахунки авторів

Найбільш ризикованим і небезпечним для здоров'я населення є будівництво сміттєспалювальних заводів, тобто четвертий сценарій $є$ неприйнятним для області. Найменш ризикованим

\section{БІБЛІОГРАФІЯ}

1. Wallis M.,Watson A. Waste - a burning issue. / Safe Energy. - 1994. - № 101. - P. 14-17.

2. Управління відходами: вітчизняний та зарубіжний досвід: посібник / [О. І. Бондар, В. Є. Барановська, М. О. Баринов та ін.] ; за ред. О. І. Бондаря. - К. : Айва Плюс Лтд, 2008. - 196 с.

3. Теоретико-методичні і практичні засади управління твердими побутовими відходами високо урбанізованих промислових регіонів. Монографія / [В. Л. Пілюшенко, I. В. Шкрабак, В. І. Антіпов та ін.]; за ред. В. Л. Пілюшенко. Донецьк : Технопак, ДонДУУ, 2009. - 338 с.

4. Мороз О. В. Економічні аспекти вирішення екологічних проблем утилізації твердих побутових відходів / О.В.Мороз, А. О. Свентух,

\section{ANNOTATION}

Pysarenko P.V., Samoilyk M.S., Dychenko O.Yu. The use of different technological solutions in the sphere of solid waste at risk assessments on public health. i безпечним для здоров'я населення та навколишнього середовища $\epsilon$ будівництво чотирьох сміттєсортувальних станцій або двох заводів 3 компостування.

О. Т. Свентух. - Вінниця : УНІВЕРСУМ - Вінниця, 2003. $-110 \mathrm{c.}$

5. Міщенко В. С. Організаційно-економічний механізм поводження 3 відходами в Україні та шляхи його вдосконалення / $\mathrm{B}$. С. Міщенко, Г. П. Виговська. - К. : Наукова думка, 2009 $294 \mathrm{c}$.

6. Онищенко В. О. Теоретико-методологічні засади управління сферою поводження 3 твердими відходами на регіональному рівні : монографія / В. О. Онищенко, М. С. Самойлік. - Полтава : Сімон, 2013. - 524 с.

7. Сайт Державної служби статистики України [Електронний ресурс]. - Режим доступу : http://www.ukrstat.gov.ua/.

The problem of waste management is one of the most important ecological-economic and social problems of regional development. Therefore, the article proposes methodological approaches to the 


\section{СІЛЬСЬКЕ ГОСПОДАРСТВО. ЕКОЛОГІЯ}

assessment of the public health from environmental pollution dealing with solid waste, which includes a comprehensive inventory of pollutant emissions and exposure assessment; determination of the risk of immediate toxic effects and the risk of chronic exposure, taking into account the combined effects of pollutants on the human body; calculation of ecological risk taking into account economic damage for environmental pollution; forecast of socio-economic development of the region for various technological solutions in the field of solid waste management, depending on the level of environmental risk.

An assessment of the impact of the existing solid waste management system on the public health on the example of the Poltava region has made it possible to establish that the greatest risk to health, as well as the economic damage caused by environmental pollution, is the first scenario - the current situation. The most risky and dangerous for the public health is the construction of waste incineration plant; this scenario is unacceptable for the region. It is substantiated that the least risky and safe for the public health and the environment in the region is the construction of four waste sorting stations or two composting plants.

Key words: public health risk, solid waste, region, technological solutions, public. 